\title{
New insights into purinergic receptor signaling in neuronal differentiation, neuroprotection, and brain disorders
}

\author{
Paromita Majumder • Cleber A. Trujillo • \\ Camila G. Lopes • Rodrigo R. Resende • \\ Katia N. Gomes • Katia K. Yuahasi • Luiz R. G. Britto • \\ Henning Ulrich
}

Received: 16 July 2007 / Accepted: 9 August 2007 / Published online: 12 September 2007

(C) Springer Science + Business Media B.V. 2007

\begin{abstract}
Ionotropic P2X and metabotropic P2Y purinergic receptors are expressed in the central nervous system and participate in the synaptic process particularly associated with acetylcholine, GABA, and glutamate neurotransmission. As a result of activation, the $\mathrm{P} 2$ receptors promote the elevation of free intracellular calcium concentration as the main signaling pathway. Purinergic signaling is present in early stages of embryogenesis and is involved in processes of cell proliferation, migration, and differentiation. The use of new techniques such as knockout animals, in vitro models of neuronal differentiation, antisense oligonucleotides to induce downregulation of purinergic receptor gene expression, and the development of selective inhibitors for purinergic receptor subtypes contribute to the comprehension of the role of purinergic signaling during neurogenesis. In this review, we shall discuss the participation of purinergic receptors in developmental processes and in brain physiology, including neuron-glia interactions and pathophysiology.
\end{abstract}

P. Majumder · C. A. Trujillo • C. G. Lopes · K. N. Gomes •

H. Ulrich $(\bowtie)$

Departamento de Bioquímica, Instituto de Química,

Universidade de São Paulo,

Av. Prof. Lineu Prestes 748,

05508-900 São Paulo, SP, Brazil

e-mail: henning@iq.usp.br

R. R. Resende • L. R. G. Britto

Departamento de Fisiologia e Biofísica,

Instituto de Ciências Biomédicas,

Universidade de São Paulo,

São Paulo 05508-900 SP, Brazil

K. K. Yuahasi

Departamento de Neurologia Clínica,

Universidade Federal de São Paulo,

São Paulo 04023-900 SP, Brazil
Keywords ATP knockout animal · neural stem cells . neurotransmitter $\cdot$ P19 embryonal carcinoma cells

\begin{tabular}{|c|c|}
\hline \multicolumn{2}{|c|}{ Abbreviations } \\
\hline $\mathrm{ACh}$ & acetylcholine \\
\hline $\mathrm{AD}$ & Alzheimer's disease \\
\hline AP & alkaline phosphatase \\
\hline ax-2 & ataxin-2 \\
\hline cdks & cyclin-dependent kinases \\
\hline CNS & central nervous system \\
\hline DRG & dorsal root ganglia \\
\hline $\mathrm{EC}$ & embryonal carcinoma \\
\hline NTPDase2 & $\begin{array}{l}\text { ectonucleoside triphosphate } \\
\text { diphosphohydrolase } 2\end{array}$ \\
\hline E-NPP & $\begin{array}{l}\text { ectonucleotide pyrophosphatase } \\
\text { phosphodiesterase }\end{array}$ \\
\hline EGF & epidermal growth factor \\
\hline E-NTPDase & $\begin{array}{l}\text { ectonucleoside triphosphate } \\
\text { diphosphohydrolase }\end{array}$ \\
\hline ES cells & embryonic stem cells \\
\hline $\mathrm{E}-5^{\prime}-\mathrm{NT}$ & ecto-5'-nucleotidase \\
\hline FGF-2 & fibroblast growth factor 2 \\
\hline GABA & $\gamma$-aminobutyric acid \\
\hline GFAP & glial fibrillary acidic protein \\
\hline IFN- $\gamma$ & interferon- $\gamma$ \\
\hline LIF & leukemia inhibitory factor \\
\hline LTP & long-term potentiation \\
\hline MAP-2 & microtubule-associated protein- 2 \\
\hline MAPK & mitogen-activated protein kinase \\
\hline MRF & microglial response factor \\
\hline MRS 2179 & $\begin{array}{l}2^{\prime} \text {-deoxy- } N^{6} \text {-methyladenosine } 3^{\prime} \text {, } \\
5^{\prime} \text {-bisphosphate }\end{array}$ \\
\hline $\mathrm{NPC}$ & neural progenitor cells \\
\hline NPC & neural stem cells \\
\hline NA & noradrenaline \\
\hline
\end{tabular}




\begin{tabular}{|c|c|}
\hline NOS & nitric oxide synthase \\
\hline NTPDase & $\begin{array}{l}\text { ectonucleoside triphosphate } \\
\text { diphosphohydrolase }\end{array}$ \\
\hline NGF & nerve growth factor \\
\hline OP & oligodendrocyte \\
\hline oxATP & oxidized ATP \\
\hline PPADS & $\begin{array}{l}\text { pyridoxalphosphate-6-azophenyl-2', } \\
\text { 4'-disulfonic acid }^{\prime}\end{array}$ \\
\hline SVZ & subventricular zone \\
\hline TGF & transforming growth factor \\
\hline TNF- $\alpha$ & tumor necrosis factor- $\alpha$ \\
\hline GAP-43 & growth-associated protein 43 \\
\hline TNAP & tissue-nonspecific alkaline phosphatase \\
\hline TNP-AT & $\begin{array}{l}2^{\prime} 3^{\prime}-O-(2,4,6 \text {-trinitrophenyl) adenosine } \\
5^{\prime} \text {-triphosphate }\end{array}$ \\
\hline
\end{tabular}

\section{Introduction}

During the last two decades, evidence for the participation of ATP as neurotransmitter in neuronal signaling was collected by Drs. Surprenant [1] and Silinsky [2]. Purine-sensitive receptors were first classified as P1 G-coupled receptors which are activated by adenosine and P2 receptors, responding to stimulation of ATP [3]. Based on receptor cloning and studying of receptor-induced signal transduction, $\mathrm{P} 2$ receptors were divided into $\mathrm{P} 2 \mathrm{X}$ receptors as ATPgated ion channels and P2Y G protein-coupled receptors [4].
The expression of purinergic receptors has been identified during development and differentiation processes [510]. Nucleotides exert a synergic effect on cell proliferation in association with growth factors, chemokines, or cytokines in early stages of development [11-13] by parallel activation of the MAP kinase pathway and/or by transactivation of growth factor receptors $[14,15]$.

The complete role of ATP action in developmental processes still needs to be elucidated. It is known that ATP activates purinergic receptors resulting in many cases in increases of intracellular free calcium concentration $\left[\mathrm{Ca}^{2+}\right]_{\mathrm{i}}$. Changes in $\left[\mathrm{Ca}^{2+}\right]_{\mathrm{i}}$ are involved in several events of differentiation and the embryogenesis process $[16,17]$. Spitzer et al. [18] showed that naturally occurring patterns of $\mathrm{Ca}^{2+}$ transients encoded neuronal differentiation. Distinct frequency patterns of $\left[\mathrm{Ca}^{2+}\right]_{i}$ elevations were sufficient to promote neuronal differentiation, including physiological neurotransmitter receptors expression [19]. ATP and UTP are the main purinergic agonists activating $\mathrm{P} 2 \mathrm{X}$ or $\mathrm{P} 2 \mathrm{Y}$ receptors. These nucleotides can be rapidly degraded in the extracellular space by ectoenzymes to ADP or UDP, subsequently activating distinct $\mathrm{P} 2 \mathrm{Y}$ receptors, or be finally degraded to adenosine, which is known to induce physiological responses via activation of P1 G protein-coupled receptors [20] (Fig. 1).

In this review article, we shall discuss the roles of purinergic signaling in neurogenesis such as cell cycle control during neural progenitor proliferation and differentiation as well as in maintaining physiology of neurons and
Fig. 1 Purine-induced signaling pathway involves the activation of $\mathrm{P} 1$ adenosine and $\mathrm{P} 2$ purinergic receptors and purine hydrolysis by ectonucleotidases. The scheme demonstrates purinergic receptor activity present in glia-glia, neuron-glia, and neuron-neuron interaction during neurogenesis as well as in the metabolism of the adult brain

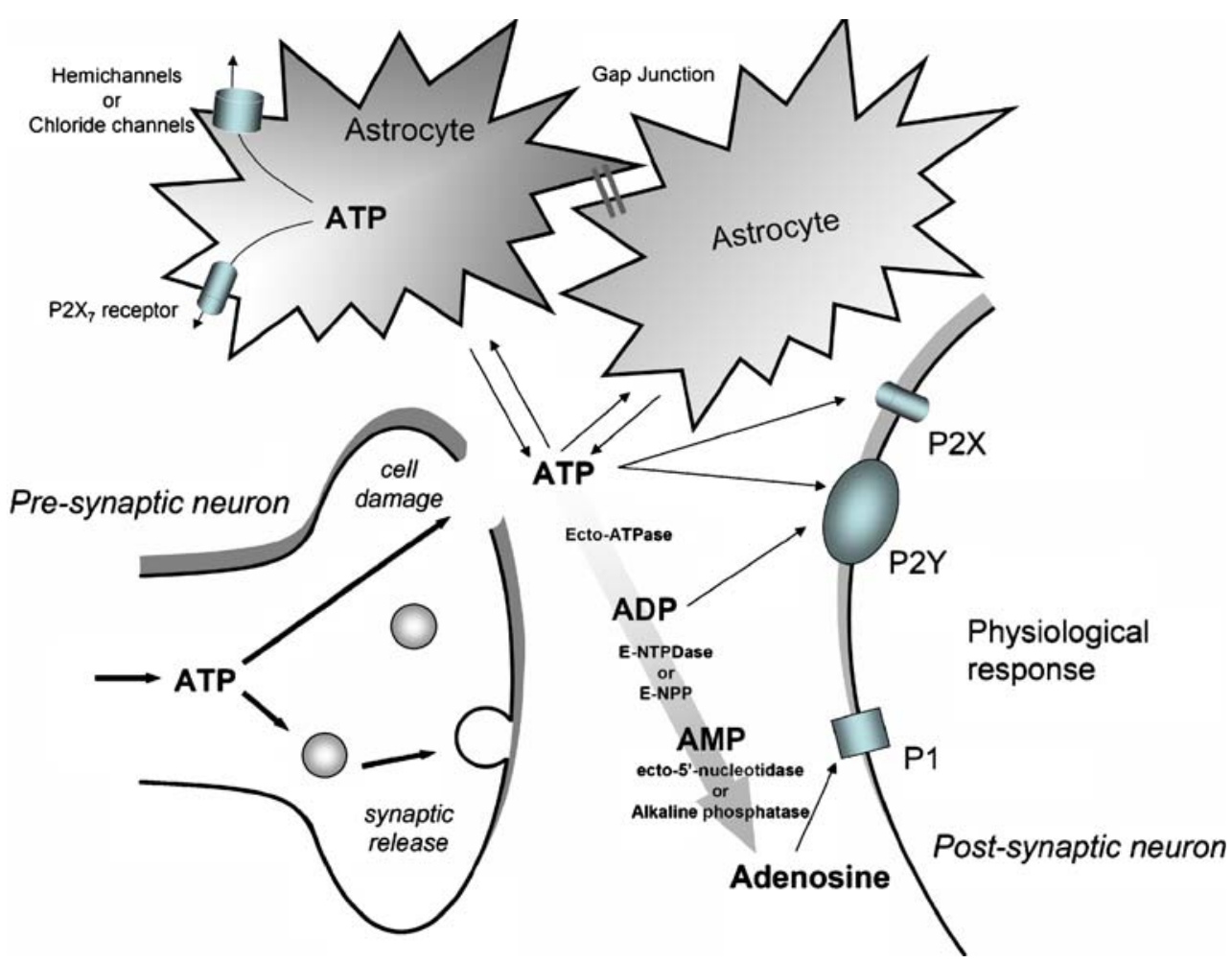


glial cells and the involvement of purinergic receptors in pathophysiology. In addition, we shall outline state-of-theart approaches used in investigation of $\mathrm{P} 2$ receptor function in physiological processes such as the use of antisense oligonucleotides, generation of knockout animals, and identification of new purinergic receptor subtype-selective drugs.

Study of purinergic receptor function during in vitro differentiation

During the development of the mammalian nervous system, neural stem cells and their derivative progenitor cells generate neurons by asymmetric and symmetric divisions [21]. P2 receptors were shown to be one of the first functionally active membrane receptors in chick embryo cells during gastrulation, in which ATP caused rapid accumulation of inositol triphosphate and $\mathrm{Ca}^{2+}$ mobilization in a similar way as acetylcholine (Ach) did via activation of muscarinic acetylcholine receptors, whereas other endocrine-acting substances such as insulin and noradrenaline (NA) induced much weaker effects in terms of intracellular calcium signaling $[22,23]$. The induction of transient fluctuation in $\left[\mathrm{Ca}^{2+}\right]_{\mathrm{i}}$ also denominated as calcium wave signaling allows for a coupling of spatial and temporal information. Thus, calcium waves have been proposed to play a role in mapping of neuronal networks [24] and to modulate neurogenesis during embryonic cortical development [25].

Neurotransmitters are prominent candidates for transcellular signals that could influence the development of embryonic neurons as they surround neural cells throughout brain development [26-29]. In addition, functional ligandgated ionic channel receptors have been identified in neural progenitor cells prior to establishing cortical and subcortical synapses [30, 31]. In this context, the extracellular signaling mechanisms controlling the various transition steps involved in adult neurogenesis are still poorly understood. One approach used to identify the function of $\mathrm{P} 2$ receptors during development and differentiation is the use of in vitro models for neuronal and glial differentiation such as embryonic and adult neural progenitor cells (NPC), also known as neural stem cells (NSC), embryonic stem (ES), and embryonal carcinoma (EC) cells.

ES cells are obtained from the inner mass cell of the blastocyst. The differentiation of these cells closely resembles the in vivo process and, therefore, provides stable models for embryonic growth and development $[32,33]$. ATP promotes cell proliferation acting through $\mathrm{P}_{2} \mathrm{X}_{3}, \mathrm{P} 2 \mathrm{X}_{4}$, $\mathrm{P}_{2} \mathrm{Y}_{1}$, and $\mathrm{P} 2 \mathrm{Y}_{2}$ receptors in murine ES cells [34]. Tissuenonspecific alkaline phosphatase (TNAP) was also detected in these cells and used as a marker for their undifferentiated stage [35].
The neuronal differentiation of EC cells, originated from irradiated embryo cells [36], also resembles early neuronal development in vivo. P19 mouse EC cells express stem cell-specific marker proteins and their phenotypic changes in specific differentiation stages are similar to those of stem cells [37]. Recently, our laboratory [38] has determined gene and protein expression of P2 receptor subtypes throughout in vitro neuronal differentiation of P19 cells as well as in the undifferentiated cell stage suggesting the participation of purinergic signaling in initiating and directing differentiation. Differential expression and activity of $\mathrm{P} 2 \mathrm{Y}_{1}, \mathrm{P}_{2} \mathrm{Y}_{2}, \mathrm{P}_{2} \mathrm{Y}_{4}, \mathrm{P} 2 \mathrm{X}_{2}$ subtypes and $\mathrm{P} 2 \mathrm{X}_{6}$ subunits were reported during neuronal maturation of $\mathrm{P} 19$ cells [38, 39]. As direct evidence for participation of purinergic receptors in neuronal differentiation, the presence of the antagonists pyridoxalphosphate-6-azophenyl-2',4'-disulfonic acid (PPADS), reactive blue 2, or suramin during differentiation of P19 neural progenitor cells (NPC) to P19 neurons resulted in reduced activity of cholinergic and glutamate NMDA receptors in differentiated P19 cells, pointing at a participation of $\mathrm{P} 2 \mathrm{Y}_{1}, \mathrm{P} 2 \mathrm{Y}_{2}$, and $\mathrm{P} 2 \mathrm{X}_{2}$ receptors.

Other in vitro neuronal and glial differentiation models used to understand the purinergic signaling are neural stem cells or progenitor cells which are isolated from the subventricular region (SVZ) located in the lateral ventricles (type B cells) or in the subgranular region of the gyrus dentatus of the hippocampus (residual radial glia) or even from the subcortical parenchyma of the cerebral cortex of embryonic and adult brain [40-42]. These regions in the adult brain act as neural stem cell reservoirs. These cells are already advanced in their differentiation stage when compared to ES or EC cells. Since NSC and NPC are capable of differentiating in both functional neurons and glial cells, they possess potential therapeutic applications such as ES cells in regeneration therapy following neuronal loss.

These NPC differentiate into olfactory, cerebellar, and retinal neurons [40] in the presence of growth factors, neurotransmitters, vasoactive peptides in vivo [43], and growth factors such as epidermal growth factor (EGF), fibroblast growth factor 2 (FGF-2), and leukemia inhibitory factor (LIF) in vitro. When exposed to a high concentration of FGF-2 in suspension, proliferating NPC form tridimensional cell aggregates denominated as neurospheres, which following induction to differentiation express neuronal marker proteins such as $\beta$-III-tubulin, microtubuleassociated protein-2 (MAP-2), and synaptophysin [44] and express $\mathrm{P}_{2} \mathrm{X}_{3}$ and $\mathrm{P} 2 \mathrm{X}_{7}$ receptors which may contribute to early $\left[\mathrm{Ca}^{2+}\right]_{\mathrm{i}}$ transients as prerequisites for further differentiation [41]. Shukla et al. [45] identified functional P2 receptors in adult mouse hippocampal progenitors in situ and the nucleoside triphosphate-hydrolyzing ectoenzyme (NTPDase) in type B cells of the SVZ [46] and in 
hippocampal progenitor cells. In adult murine NPC of SVZ, $\mathrm{P} 2 \mathrm{Y}_{1}$ receptor activity mainly contributes to $\left[\mathrm{Ca}^{2+}\right]_{\mathrm{i}}$ transients with some participation of $\mathrm{P}_{2} \mathrm{Y}_{2}$ receptors. The presence of the specific $\mathrm{P}_{2} \mathrm{Y}_{1}$ receptor antagonist MRS 2179 resulted in diminished cell proliferation in neurospheres due to reductions of $\left[\mathrm{Ca}^{2+}\right]_{i}$ transients. Similar results were obtained with NPC from SVZ of $\mathrm{P}_{2} \mathrm{Y}_{1}$ receptor knockout mice [47]. $\mathrm{P} 2 \mathrm{Y}_{1}$ receptor-deficient mice are viable; however, they have deficits in platelet aggregation [48]. It is suggested that the purine signaling underlies autocrine or paracrine mechanisms and $\mathrm{P}_{2} \mathrm{Y}_{1}$ and $\mathrm{P} 2 \mathrm{Y}_{2}$ receptors are important for NPC differentiation [47]. These models are useful tools to study the roles of P2 receptor signaling in early stages of development and differentiation. The importance of ATP release and purinergic signaling has not only been demonstrated in developmental progenitor cell expansion and neurogenesis, but also in persistent progenitor cells of the adult brain [49].

Expression of purinergic receptors during development of the central nervous system

Purinergic signaling pathways are also involved in embryonic neurogenesis in much the same way as already discussed for in vitro differentiation models. ATP mediates elevation of $\left[\mathrm{Ca}^{2+}\right]_{i}$ and proliferation of immortalized human stem cells from embryonic telencephalon and mouse embryonic neurospheres [50,51]. $\mathrm{Ca}^{2+}$ waves through radial glial cells in slices of the embryonic rat ventricular zone are mediated by $\mathrm{P}_{2} \mathrm{Y}_{1}$ receptors. Disrupting $\mathrm{Ca}^{2+}$ waves between embryonic NPC reduced ventricular zone cell proliferation during the peak of embryonic neurogenesis [25].

ATP directly contributes to modulate network-driven giant depolarizing potentials in the rat hippocampus during early stages of postnatal development [52]. In the developing hippocampal system a trophic role of ATP and the involvement of $\mathrm{P} 2$ receptor subtypes in shaping interneuronal connections during neuronal differentiation have been suggested [53]. Alterations of the regulation of embryonic growth by purinergic receptors might be involved in the onset of morphological malformations [54]. During rat postnatal development ectonucleotidase activity in the cerebral cortex steadily increases, reaching maximum values at 21 days of age [55]. Several P2Y and P2X receptors were shown to be dynamically expressed in the pre- and postnatal central and peripheral nervous system [56-59]. ATP inhibited motor axon outgrowth during early embryonic neurogenesis, most likely through the $\mathrm{P}_{2} \mathrm{X}_{3}$ receptor, and it was speculated that $\mathrm{P} 2 \mathrm{X}_{7}$ receptors might be involved in programmed cell death during embryogenesis [58].

From all of the studied P2X receptors, homomeric $\mathrm{P} 2 \mathrm{X}_{2}$ receptors were the first expressed in the rat central nervous system (CNS) on embryonic day 14 (E14) [56]. On E14, heteromeric receptors were formed by $\mathrm{P} 2 \mathrm{X}_{2 / 3}$ receptor subunits. $\mathrm{P} 2 \mathrm{X}_{3}$ receptor immunoreactivity was detected in cranial motor neurons as early as on E11, when neurons exited the cell cycle and started axon outgrowth, as well as postnatally on days 7 and 14 (P7 and P14) [56, 60]. Moreover, expression of $\mathrm{P}_{2} \mathrm{X}_{3}$-containing heteromeric receptors and other subunits was developmentally regulated in nucleus ambiguous motoneurons [61]. From E14 onwards $\mathrm{P}_{2} \mathrm{X}_{7}$ receptors were also expressed in the embryonic brain. For instance, in primary cultures of human fetal astrocytes basal levels of $\mathrm{P}_{2} \mathrm{X}_{7}$ receptor mRNA transcription and protein expression were detected [62]. Sperlágh et al. [63] have demonstrated that ATP regulates glutamate release via activation of $\mathrm{P} 2 \mathrm{X}_{7}$ receptors. $\mathrm{P} 2 \mathrm{X}_{7}$ receptor-induced excessive glutamate release alters $\mathrm{Ca}^{2+}$ homeostasis, subsequently resulting in activation of the apoptosis-related caspase cascade [64].

$\mathrm{P} 2 \mathrm{X}$ receptor expression was downregulated in Purkinje cells and deep cerebellar nuclei at P21 and P66 rat embryonic stages, with the exception of $\mathrm{P}_{2} \mathrm{X}_{5}$ receptors whose immunoreactivity in granular cells was increased [65]. Evidence for participation of P2X receptors in different developmental processes such as neurite outgrowth (involving $\mathrm{P}_{2} \mathrm{X}_{3}$ receptors), postnatal neurogenesis (related to $\mathrm{P} 2 \mathrm{X}_{4}$ and $\mathrm{P} 2 \mathrm{X}_{5}$ receptor expression), and cell death (possibly involving $\mathrm{P}_{2} \mathrm{X}_{7}$ receptors) was collected. However, $\mathrm{P} 2 \mathrm{X}_{1}$ and $\mathrm{P} 2 \mathrm{X}_{6}$ receptor subunits may not play a role in neuronal development [58].

Neocortical neurons from 2-week-old rats possess a quite elaborated purine-triggered signaling system which includes both $\mathrm{P} 2 \mathrm{Y}$ and $\mathrm{P} 2 \mathrm{X}$ receptor activation [66]. Weissman et al. [25] showed that $\left[\mathrm{Ca}^{2+}\right]_{\mathrm{i}}$ waves and subsequent ATP release, with consequent $\mathrm{P}_{2} \mathrm{Y}_{1}$ receptor activation, accompanied radial glial cell-derived neurogenesis in cultured slices of the developing rat forebrain, as mentioned above. Moreover, the importance of calcium signaling for differentiation of NPC has been studied [67, 68], and direct evidence for the participation of $\mathrm{P}_{2} \mathrm{Y}_{1}$ receptor-activated pathways in the early development has been provided by Scemes et al. [69]. P2Y receptors (particularly the $\mathrm{P}_{2} \mathrm{Y}_{1}$ subtype) were widely expressed in the embryonic rat brain as early as on E11 [57]. There was a marked decrease in the concentration of mRNA coding for $\mathrm{P}_{2} \mathrm{Y}_{1}$ receptors and upregulation of mRNA transcription coding for $\mathrm{P}_{2} \mathrm{Y}_{2}$ receptors in freshly isolated astrocytes of developing rat hippocampus [57].

Functional interactions between neurons and glia: a physiological overview

An increasing amount of evidence, initiated by the neuronglia unit idea proposed by Hyden [70], indicates that glial cells, once referred to as a simple support portion in the 
CNS, are now considered indispensable functional partners of neurons [71], both in physiological and pathological conditions. However, many questions remain unanswered: (1) how glia detects and interacts with neural function; (2) does neuron-glia signaling play a significant role in synaptic transmission and plasticity; and (3) how glial cells can communicate with other glial cells.

Another important subject related to the interaction between glia and neurons emerges in neurogenesis. There is now a general agreement that the adult mammalian nervous system possesses many characteristics of astrocytes. The importance of glia in neuronal development was confirmed in a recent study showing that the number of GFAP (glial fibrillary acidic protein)-containing cells was reduced following transgenic targeting of adult mouse subependymal and subgranular zones, resulting in an almost complete loss of neurogenesis [72, 73]. In addition to assisting migration of neurons to their correct position and managing neurite outgrowth to their final communication targets [74, 75], glial cells have become an essential key for understanding neuronal differentiation by promoting initial stem cell proliferation and instructing undifferentiated cells to adopt a neuronal fate $[76,77]$.

In the mature brain, the proximity of astrocytes to neuronal synapses or to the blood-brain barrier makes these cells appropriate to control water diffusion and ion concentration in extracellular spaces $[71,78]$. In particular, astrocytes regulate homeostatic environment and neurotransmitter levels by functional syncytium, in which gap junctions and specific membrane carriers play an important role [79-81]. In addition, glial cells produce and release a vast number of neurotrophins, including fibroblast growth factor, nerve growth factor, and transforming growth factor, which directly interfere in neuron physiology and coordinate developmental processes [71, 82-85].

ATP release and degradation, connecting adenosinergic and purinergic systems

As already mentioned, it is well documented that glial cells may directly alter neuronal activity by releasing neurotrophins and consequently modulating neurotransmitter release in the synapse [86, 87]. One of the main mechanisms connecting the neuron-glia system is believed to be mediated by the release of glutamate from glial cells $[88,89]$. In this context, growing evidence indicates that purinergic receptor ligands are widely involved in the cellcell signaling mechanism by acting as neurotransmitters or neuromodulators released by glial cells to control synaptic transmission in the CNS, as part of multiple functions of astrocytes [22, 90, 91] (Fig. 1).

ATP is an ideal molecule for cell signaling due to its intrinsic properties such as its small size, diffusing molecule rate, instability and low concentration in the extracellular environment, and impossibility to cross the plasma membrane $[92,93]$. These properties imply the presence of particular pathways for ATP release that could be associated with cellular excitation/response and cell-cell signaling [94, 95]. First, ATP may be stored in synaptic vesicles alone or with other neurotransmitters and then released, as a classic synaptic mechanism in the peripheral or central nervous system [96, 97]. Second, a nonvesicular mechanism of ATP release could be observed through gap junction hemichannels, ATP-binding cassette proteins, $\mathrm{P}_{2} \mathrm{X}_{7}$ receptor pores in glial cells, and via chloride channels [98-101]. Third, ATP could be released due to cytolysis or cell damage. While this is not a physiological mechanism, it takes place following biological trauma and contributes to pathological conditions [102].

Subsequent to these mechanisms, the metabolism of the released ATP is regulated by a vast number of different families of ectonucleotidases in the synaptic cleft, including the ectonucleoside triphosphate diphosphohydrolase (E-NTPDase) and the ectonucleotide pyrophosphatase phosphodiesterase (E-NPP) which catalyze the degradation of ATP to ADP or AMP. The degradation to adenosine is mediated by ecto-5'-nucleotidase (E-5'-NT) and alkaline phosphatase [91, 103] (Fig. 1). Consequently, the reaction products resulting from the ATP hydrolysis may bind to P2 receptors, in the case of $\mathrm{ADP}$, or to $\mathrm{P} 1$ receptors in the case of adenosine [104].

The adenosinergic receptor ligand adenosine is recognized as an important regulator of cellular homeostasis in the CNS and may be involved in the prevention or induction of apoptosis [105]. The reduction of ectonucleotidase activity in certain pathological conditions provided additional evidence for the accumulation of ATP in the extracellular environment [20]. Therefore, the complexity of the communication of neural and nonneural cells expands the functional significance by the interaction of the purinergic receptors in association with a variety of neurotransmitter systems.

\section{ATP-mediated neuron-glia signaling}

Novel studies in the purinergic field began to converge with glial research as it became more widely accepted that ATP is released through synaptic vesicles and thus accessible to perisynaptic glial cells, allowing them to detect neuronal activity. In particular, glial cells are responsive to ATP, as all types of glia, such as astrocytes, oligodendrocytes, microglia, and Schwann cells, express purinergic receptors [91]. In Schwann cells and oligodendrocytes, ATP-mediated signaling predominantly occurs through $\mathrm{P} 2 \mathrm{Y}$ receptors, which in turn trigger intracellular $\mathrm{Ca}^{2+}$ release [106, 107]. However, the function of $\mathrm{P} 2 \mathrm{X}_{1-6}$ receptors in astrocytes 
remains unclear, although P2X-mediated currents could be detected in astrocyte cells in culture, and $\mathrm{P} 2 \mathrm{X}_{7}$ receptors are widespread in these cells with possible contribution to pathological conditions [108, 109].

Glial cells express many types of neurotransmitter receptors and conventionally are considered to be nonexcitable $[110,111]$. However, a surprising observation was reported by Dani et al. [112] that synaptic transmission may propagate to glial cells as calcium waves, inducing membrane depolarization and regulating neurotransmitter release. These properties of glial cells suggest possible rapid communications between neurons and glia during synaptic transmission. This glial communication mechanism allows the released ATP to act onto adjacent astrocytes and neurons, thus supporting the propagation of $\mathrm{Ca}^{2+}$ waves in glial syncytium [113]. For example, in neuronal-glial cocultures prepared from hippocampus, ATP secreted by astrocytes was shown to inhibit glutamatergic synapses through activation of $\mathrm{P} 2 \mathrm{Y}$ receptors [114].

The glial communication mechanism based on $\mathrm{Ca}^{2+}$ wave propagation could be inhibited by P2 receptor blockers or enzymes that rapidly hydrolyze extracellular ATP [115]. A stimulation applied to a single astrocyte in cocultures of rat forebrain astrocytes and associated neurons caused an elevation of $\left[\mathrm{Ca}^{2+}\right]_{\mathrm{i}}$ and induced $\mathrm{Ca}^{2+}$ wave propagation in dorsal spinal cord through $\mathrm{P}_{2} \mathrm{Y}_{1}$ receptor activation [116] and glutamate release [117]. This new finding provided a parallel mechanism of intercellular communication that could allow astrocytes to detect synaptic function, propagate the information through neighboring glial cells, and then influence synaptic function in a distant part of the nervous system.

Purinergic receptor-calcium signaling in glial cells plays important roles during CNS development. $\mathrm{P}_{2} \mathrm{X}_{1}, \mathrm{P} 2 \mathrm{X}_{4}$, and $\mathrm{P} 2 \mathrm{X}_{7}$ receptors were expressed in microglia at rat embryonic stage (E16) [59]. Moreover, changes in $\mathrm{P}_{2} \mathrm{X}_{4}$ receptor expression in microglial cells during postnatal development of the rat cerebellum have been reported. $\mathrm{P}_{2} \mathrm{X}_{5}$ receptor immunoreactivity was also upregulated in microglia and granular cells. Both $\mathrm{P} 1$ and $\mathrm{P} 2$ receptors contribute to the modulation of oligodendrocyte (OP) development, since they have been shown to exert similar effects on OP proliferation and differentiation [118].

The majority of the studies of ATP action have been concerned with the short-term P2 receptor signaling that occurs in neurotransmission and in secretion [119]. Furthermore, there is increasing evidence that purines and pyrimidines can have trophic roles in neuritogenesis [120, 121], regeneration [122], and proliferation [123]. However, some purines by themselves have limited trophic effects in a few types of cells; they appear to be much more effective as neuritogenic agents when they are combined with other trophic factors, such as NGF. For instance, inosine and 5'
AMP alone do not elicit neurite extensions in PC12 cells [124].

Heine et al. [53] demonstrated that $\mathrm{P} 2$ receptor activation induced fiber outgrowth in organotypic cocultures in rat hippocampus. Fiber outgrowth was inhibited in the presence of the purinergic antagonist PPADS, suggesting the involvement of P2 receptors. In another study, the synergistic interaction between bFGF and ATP was reported on DNA synthesis in primary cultures of rat cortical astrocytes. ATP and bFGF induced a twofold and tenfold incorporation of $\left[{ }^{3} \mathrm{H}\right]$ thymidine into astrocytes, respectively, but when ATP and bFGF were added at the same time a 50 -fold increase in $\left[{ }^{3} \mathrm{H}\right]$ thymidine incorporation was observed [12].

\section{Neuroprotection}

ATP can activate $\mathrm{P} 2 \mathrm{X}_{7}$ receptors in astrocytes to release glutamate, GABA, and also ATP which might regulate the excitability of neurons in certain pathological conditions [125]. It has been suggested that astrocytes can sense the severity of damage in the CNS by the amount of ATP released from damaged cells and that extracellular ATP concentration and the corresponding subtype of activated astrocytic $\mathrm{P} 2$ receptor modulate the tumor necrosis factor- $\alpha$ (TNF- $\alpha$ )-mediated inflammatory response [126]. After mechanical brain injury, the administration of PPADS facilitated the recovery of pathologically changed electroencephalograms [127]. These results suggest that interference with the ATP-induced excitatory responses could provide neuroprotection and possible therapeutic consequences.

Evidence for a neuroprotective role was also found for the adenosine $A_{1}$ receptor in hippocampus. This cerebral region is highly sensitive to hypoxia and ischemia. The study of the action of hypoxia on synaptic transmission in hippocampal slices has suggested that substances being released during hypoxia, such as GABA, ACh, and even glutamate, may also play neuroprotective roles. However, the actions of these neurotransmitters become evident only when activation of $\mathrm{P} 1$ receptors is impaired, suggesting a critical role for this receptor during hypoxic events. These substances can operate in a redundant or even overprotective manner, acting as a substitute for some adenosine actions when the nucleoside is not operative [128].

Neuroimmune interactions

Microglia, the immune cells of the CNS, can be activated by purines and pyrimidines to release inflammatory cytokines such as IL-1, IL-6, and TNF- $\alpha$. However, hyperstimulation of the immune reaction in the brain may accelerate neuronal damage. The $\mathrm{P} 2 \mathrm{X}_{7}$ receptor is considered to have a potentially pivotal role in the regulation of 
various inflammatory conditions. ATP selectively suppresses the synthesis of the inflammatory protein microglial response factor through calcium influx via $\mathrm{P} 2 \mathrm{X}_{7}$ receptors in microglia [129], which also leads to enhancement of interferon- $\gamma(\mathrm{IFN}-\gamma)$-induced type II nitric oxide synthase (NOS) activity $[130,131] . \mathrm{P}^{2} \mathrm{X}_{7}$ receptor activity also participated in ATP-induced IL-1 release from macrophages and microglia that had been primed with substances such as bacterial endotoxin [132] and was shown to stimulate the transcription of nuclear factor $\mathrm{kB}, \mathrm{TNF}-\alpha[133]$, the stressactivated protein kinases (SAPK)/JNK pathway [134], and the production of 2-arachidonoylglycerol, which is also involved in inflammation induction by microglial cells.

$\mathrm{P} 2 \mathrm{Y}$ rather than $\mathrm{P} 2 \mathrm{X}_{7}$ receptors seem to have a major role in the IL-6 production by microglial cells [135]. ATP evoked the release of plasminogen [136] and IL-6 [135]. The stimulation of microglia by either ATP or BzATP revealed neurotoxic properties and the involvement of the $\mathrm{P}_{2} \mathrm{X}_{7}$ receptor has been reported in excitotoxic/necrotic and apoptotic degeneration [109].

\section{Neurological disorders}

Epilepsy Several anti-epileptic agents reduce the ability of astrocytes to transmit $\mathrm{Ca}^{2+}$ waves, raising the possibility that blockade of ATP-induced $\left[\mathrm{Ca}^{2+}\right]_{\mathrm{i}}$ transients in astrocytes by purinergic receptor antagonists could offer new treatments for epileptic disorders. Antiepileptic effects of adenosine are mostly due to the well-known inhibitory actions of P1 receptors on synaptic transmission in the hippocampus. However, as recently pointed out, adenosine actions are not limited to presynaptic actions on glutamate release [137]. The intraventricular injection of high doses of ATP in rats evoked severe chronic-tonic convulsions, whereas lower doses of ATP or adenosine elicited a kinetic state with muscle weakness [138]. $\mathrm{P} 2 \mathrm{X}_{2}$ and $\mathrm{P} 2 \mathrm{X}_{4}$ receptor expression in the hippocampus of seizure-prone gerbils was significantly reduced compared with that of normal gerbils [139]. $\mathrm{GABA}_{\mathrm{A}}$ receptors mediated modulation of expression of both $\mathrm{P} 2 \mathrm{X}_{2}$ and $\mathrm{P} 2 \mathrm{X}_{4}$ receptors, which may play an important role in the regulation of seizure activity in the gerbil hippocampus [139]. $\mathrm{P}_{2} \mathrm{X}_{7}$ receptors are thought to play a definite, but not yet well defined role in epilepsy. Treatment with the $\mathrm{GABA}_{\mathrm{B}}$ receptor agonist baclofen and antagonist phaclofen resulted in increased and decreased $\mathrm{P}_{2} \mathrm{X}_{7}$ receptor expression in hippocampus, respectively [140]. These purinergic receptor responses were interpreted as compensatory responses to the modulation of $\mathrm{GABA}_{\mathrm{B}}$ receptor function [140]. It is noteworthy to mention that this positive relationship between $\mathrm{P} 2 \mathrm{X}$ and $\mathrm{GABA}_{\mathrm{A}}$ receptors was also reported for the spinal cord [141] and dorsal root ganglia (DRG) [142]. In these populations of neurons, ATP-mediated $\mathrm{P} 2 \mathrm{X}$ receptor function may partic- ipate in neuronal transmission accompanied by GABAmediated actions [139].

Pain The heteromeric channel comprised of $\mathrm{P}_{2} \mathrm{X}_{2}$ and $\mathrm{P}_{2} \mathrm{X}_{3}$ subunits was expressed almost exclusively in a subset of primary afferents implicated in nociception [143-145]. It has been observed that mechanical allodynia is reduced in mice with deleted $\mathrm{P} 2 \mathrm{X}_{3}$ receptor genes [146, 147] in agreement with data obtained in rats that have been treated with intrathecal antisense oligonucleotides reducing expression of $\mathrm{P}_{2} \mathrm{X}_{3}$ receptors [148] or with the selective antagonist for $\mathrm{P}_{2} \mathrm{X}_{3}$ and $\mathrm{P} 2 \mathrm{X}_{2} / 3$ receptors $\mathrm{A}-317491$ [148, 149]. $\mathrm{P} 2 \mathrm{X}_{3}$ receptor knockout mice showed additional defects in afferent pathways.

The $\mathrm{P} 2 \mathrm{X}_{4}$ receptor is also implicated in pain sensation. Activation of dorsal horn microglia and tactile allodynia developing several days after ligation of a spinal nerve were greatly reduced when gene expression of $\mathrm{P} 2 \mathrm{X}_{4}$ receptor in the dorsal horn had been inhibited by the presence of intrathecal antisense oligonucleotides [150]. Accordingly, intraspinal administration of microglia following induction of expression and activity of $\mathrm{P} 2 \mathrm{X}_{4}$ receptors produced tactile allodynia in naive rats. Intrathecal administration of cultured brain microglia produced allodynia, but only when the cells had been pretreated with ATP [150]. The inhibition of $\mathrm{P}_{2} \mathrm{X}_{4}$ receptor activity in microglia might be a new therapeutic strategy for pain induced by nerve injury.

Alzheimer's disease Alzheimer's disease (AD) is caused by extracellular deposition of amyloid $\beta$-peptide, which can damage neurons, leading to their dysfunction and death [151]. ATP and, in particular, aluminum-ATP promoted the formation of thioflavin T-reactive fibrils of $\beta$-amyloid and an unrelated amyloidogenic peptide, which could be blocked by suramin [152].

Microglial cells are believed to contribute to the progression of $\mathrm{AD}$ and are known to release proinflammatory neurotoxic substances. Extracellular ATP, acting through the $\mathrm{P} 2 \mathrm{X}_{7}$ receptor, can alter $\beta$-amyloid peptideinduced cytokine secretion from human macrophages and microglia and thus may be an important modulator of neuroinflammation in $\mathrm{AD}$ [153]. $\mathrm{P} 2 \mathrm{X}_{7}$ receptors mediate superoxide production in primary microglia, and the expression of this receptor subtype was specifically upregulated around $\beta$-amyloid plaques in a transgenic mouse model of AD [154].

In contrast to the control human brain, the $\mathrm{P}_{2} \mathrm{Y}_{1}$ receptor was colocalized with a number of characteristic $\mathrm{AD}$ structures such as neurofibrillary tangles, neuritic plaques, and neuropil threads in the hippocampus and cortex [155]. In general, control brain tissue exhibited a greater and more abundant level of $\mathrm{P}_{2} \mathrm{Y}_{1}$ receptor immunostaining than $\mathrm{AD}$ tissue did, probably due to severe neuronal cell degenera- 
tion in most $\mathrm{AD}$ brains. The intense $\mathrm{P} 2 \mathrm{Y}_{1}$ receptor staining observed over pathological AD structures might imply that this receptor is involved either directly or indirectly in signaling events mediating neurodegeneration of pyramidal cells. Alternatively, $\mathrm{P} 2 \mathrm{Y}_{1}$ receptors might have other diverse signaling roles, possibly involved in the production of intracellular tau deposits or might even serve to stabilize these tangle structures in some way [156].

Ischemia/hypoxia Under pathological conditions of hypoxia or ischemia, extracellular purine nucleotides leak from damaged cells and thereby may reach high concentrations in the extracellular space [157]. A direct participation of extracellular ATP and P2 receptors in ischemic stress has been reported in various cellular systems [157-160]. For example, $\mathrm{P} 2 \mathrm{X}_{2}$ and $\mathrm{P} 2 \mathrm{X}_{4}$ receptor expression in neurons and microglia, respectively, in the hippocampus of gerbils was upregulated following transient global ischemia [161]. Increased $\mathrm{P}_{2} \mathrm{X}_{7}$ receptor expression in astrocytes, microglia, and neurons appears to contribute to the mechanisms of cell death caused by in vivo and in vitro ischemia [162, 163]. Following induction of ischemia $\mathrm{P}_{2} \mathrm{X}_{7}$ receptor mRNA transcription and protein expression were elevated in cultured cerebellar granule neurons and organotypic hippocampal cultures [163]. Hence, the $\mathrm{P} 2 \mathrm{X}_{7}$ receptor is apparently an important element in the mechanisms of cellular damage induced by hypoxia/ischemia. In many cell types, the activation of the $\mathrm{P}_{2} \mathrm{X}_{7}$ receptor led to rapid cytoskeletal rearrangements, such as membrane blebbing and cell lysis [164]. $\mathrm{P}_{2} \mathrm{Y}_{1}$ receptors are intensely expressed in Purkinje cells in deep layers of the cerebral cortex and in ischemia-sensitive areas of the hippocampus [165]. In conclusion, extensive evidence demonstrates a postischemic time- and region-dependent upregulation of $\mathrm{P} 2 \mathrm{X}_{2,4,7}$ and $\mathrm{P}_{2} \mathrm{Y}_{1}$ receptor subtypes in neurons and glial cells and suggests a direct role of $\mathrm{P} 2$ receptors in the pathophysiology of cerebral ischemia in vitro and in vivo.

Trauma and axotomy $\mathrm{P} 2$ receptors are suggested to be involved in neuronal reactions after axotomy. Colocalization and temporal coactivation of purinergic and nitrergic markers support this idea, indicating possible interactions between these two systems [166]. Following peripheral nerve lesions, $\mathrm{P} 2 \mathrm{X}_{3}$ receptor expression in DRG neurons was changed [167]. The increased expression of $\mathrm{P} 2 \mathrm{X}_{3}$ receptor mRNA in intact neurons indicates a role of this subtype in the post-injury pathomechanism in primary sensory neurons [167]. After spinal cord injury, large regions of the peritraumatic zone were characterized by a sustained process of pathologically high ATP release [168]. Spinal cord neurons express $\mathrm{P}_{2} \mathrm{X}_{7}$ receptors, and exposure to ATP led to high-frequency spiking, irreversible increases in $\left[\mathrm{Ca}^{2+}\right]_{\mathrm{i}}$ and cell death. The administration of $\mathrm{P} 2$ receptor antagonists (PPADS, oxATP) after acute impact injury significantly improved functional recovery and diminished cell death in the peritraumatic zone [168]. The involvement of $\mathrm{P}_{2} \mathrm{X}_{1}$ and $\mathrm{P} 2 \mathrm{X}_{2}$ receptors in neuronal reactions after hemicerebellectomy was also described [169]. Furthermore, neuronal NOS and P2 receptors were colocalized and showed temporal coactivation after cerebellar lesions, indicating a close relationship between these two systems [166]. In addition, in this mixed model of differentiation and axotomy, the colocalization of ataxin-2 (ax-2, involved in resistance to degeneration phenomena, which may be lost after mutation)-immunopositive cells and $\mathrm{P} 2 \mathrm{X}_{2}$ receptors was demonstrated in neurons, and post-lesional induction of $\mathrm{P}_{2} \mathrm{X}_{1}$ receptor and ax-2 immunoreactivity was reported as well [170]. In vivo treatment of $\mathrm{P}_{2} \mathrm{Y}_{2}$ receptor-expressing sciatic nerves with ATP- $\gamma \mathrm{S}$ increased expression levels of the growth-associated protein 43 (GAP43) as a marker for axonal growth in wild-type but not in $\mathrm{P}_{2} \mathrm{Y}_{2}-/-$ mice [171].

Possible therapeutic manipulations to modulate astrocytic proliferation and to diminish glial scar formation in the adult brain and during development include the use of drugs known to interfere with nucleotide synthesis. Pekovic et al. [172] showed that treatment with the purine nucleoside analogue ribavirin (Virazole; $1-\beta$-D-ribofuranosyl-1,2,4-triazole-3-carboxamide) downregulates the process of reactive gliosis after sensory motor cortex lesion of the adult brain and facilitates re-establishing synaptic connections with the denervated cells at the lesion site. This may be a useful approach for improving neurological recovery from brain damage. The antiproliferative effect of ribavirin is due to the inhibition of de novo nucleic acid synthesis after depletion of GTP and dGTP pools with consequent impairment of specific transduction pathways.

\section{ATP-induced effects on cell cycle progression}

There is evidence showing that extracellular ATP enhances the expression of cell cycle regulating proteins $[173,174]$. Progression of the cell cycle is highly controlled. Cyclins are synthesized and degraded in a synchronous way due to changing transcription or proteolysis rates, thereby directing the periods of the cellular cycle. Cyclins interact with cyclin-dependent kinases (cdks) resulting in activation of their kinase activity, phosphorylating their targets and themselves, and regulating the specific progression of the cell cycle through checkpoints [175].

Proliferation rates in mammalians are largely determined during the G1 phase of the cell cycle. The relevant proteins include three D-type cyclins (D1, D2, and D3) that, in different combinations, bind to and allosterically regulate one of two cdk subunits, cdk4 and cdk6, as well as the E-type 
cyclins (E1 and E2), which govern the activity of a single catalytic subunit, cdk2 [176]. Various combinations of Dtype cyclins are expressed in different cell types, whereas cyclin E-cdk2 complexes are ubiquitously expressed [177].

Two families of cdk inhibitors regulate the activity of G1-type cyclins-cdks complexes: the Ink4 family (p16, $\mathrm{p} 15, \mathrm{p} 18$, and $\mathrm{p} 19)$, which blocks the activity of cyclin Dcdk4-6 complexes, and the Cip/Kip family (p21, p27, and p57), which preferentially inhibits cyclin E-cdk2 complexes and also acts as a scaffold for the catalytically active cyclin D-cdk4-6 complexes. In addition to cyclins and cdks, mitogen-activated protein kinase (MAPK) is also believed to have a role in induction of cell proliferation. Therefore, cyclin D-dependent kinases may play a role in controlling the cell cycle of embryonic and maybe neural progenitor cells. In addition MAPK is also believed to have a role in induction of cell proliferation. Extracellular ATP induces $\mathrm{Ca}^{2+}$-dependent MAPK activation via stimulation of P2 receptors in neonatal rat astrocytes [178]. On the other hand, cell proliferation is associated with activation of diverse proteins. Positive regulators include cyclins and their partners with catalytic activity (cdks), which are essential for progression of the cells through each phase of the cell cycle and various cell cycle checkpoints [179, 180]. The regulation of cyclin D1 expression is also mediated by the Ras/ERK signaling pathways [181, 182]. Raf/MEK/ERK and PI3-K/Akt signaling pathways can act in synergy to promote the G1-S phase cell cycle progression in both normal and cancer cells [183, 184]. The promoter for cyclin D1 contains an AP-1 site, and the ectopic expression of either $c$-fos or $c$-jun induces cyclin D1 mRNA expression $[185,186]$. In many cell types, phosphatidylinositol (PI)-3-kinase-dependent signaling pathways also regulate cyclin D1 expression [187]. It was also reported that the control of the cell cycle regulatory proteins was dependent on PI3-kinase and p44/42 MAPK pathways, indicating that extracellular ATP alone is sufficient to induce cell cycle progression beyond the G1 phase of the cell cycle. These findings also suggest that, once P2 receptors are activated, protein kinase $\mathrm{C}(\mathrm{PKC})$ transmit signals to the nucleus through one or more of the MAPK cascades, which may include Raf-1, MEK, and ERK, and stimulate transcription factors such as myc, max, fos, and jun. Moreover, MAPKs are upstream regulators of cdk2 and cdk4 expression. It has been reported that p44/42 MAPK phosphorylation is essential and sufficient for the increase in cdk2 [188, 189] and decrease in p27Kip1 expression [190, 191]. However, Delmas et al. [192] provided evidence that $\mathrm{p} 44 / \mathrm{p} 42$ MAPK activation triggers p27Kip1 degradation independently from cdk2/cyclin E in NIH 3T3 cells. As described above, ATP regulation of the MAPK and cdk-cyclin complex has not been elucidated in other types of cells [193].
It is documented in the literature that purinergic receptor inhibitors interfere with the $\mathrm{S}$ phase of the cell cycle. Neurospheres treated with the purinergic receptor antagonists reactive blue 2 or suramin are mostly in $\mathrm{S}$ phase $(5.7 \pm 0.3 \%$ or $8.4 \pm 2.3 \%$ ) when compared to untreated control neurospheres with $16.4 \pm 1.8 \%$ of the cells being in $\mathrm{S}$ phase. Moreover, neurosphere cultures treated with suramin or reactive blue 2 showed an increase in the expression of the tumor suppressor p27 as a strong regulator of cell division [49].

The discussed findings led to the suggestion that extracellular ATP plays an important physiological role during mammalian embryonic development by stimulating proliferation of ES cells, and therefore P2 receptor agonists and antagonists might provide novel and powerful tools for modulating embryonic cell functions. In conclusion, P2X and $\mathrm{P} 2 \mathrm{Y}$ purinergic receptors can promote proliferation of ES cells as well as of progenitor cell types by a mechanism by that ATP induces increases in $\left[\mathrm{Ca}^{2+}\right]_{\mathrm{i}}$, leading to activation of PKC, PI3-kinase/Akt, p38, and p44/42 MAPK, followed by an alteration in the cdk-cyclin complex with p21 and p27, which are involved in stimulation of cell proliferation.

\section{Pharmacological approaches}

Most purinergic receptors do not have specific inhibitors. Therefore, P2 receptor agonists and antagonists acting on most of the purinergic receptor subtypes are widely used in experimental approaches to study biological functions of these receptors. Such approaches are feasible, since these compounds mostly have higher affinities to some P2 receptor subtypes than to other ones. As an example, we have used suramin, PPADS, and reactive blue 2 to study the participation of $\mathrm{P} 2 \mathrm{Y}_{1}, \mathrm{P}_{2} \mathrm{Y}_{2}$, and $\mathrm{P} 2 \mathrm{X}_{2}$ receptors in neuronal differentiation of P19 EC cells [38].

One possible approach towards a subtype-specific inhibitor would be based on results from P2 receptor structure determination. Using site-directed mutagenesis it has been possible to understand which amino acids are involved in ATP binding and to identify allosteric sites in purinergic receptors. The knowledge obtained on location and structural features of ligand and inhibitor binding sites is used in rational based drug design of selective purinergic subtype antagonists. Alternatively, combinatorial libraries formed by vast amounts of possible ligands can be employed for discovery of subtype-specific inhibitors.

A-317491 was identified as a specific inhibitor for $\mathrm{P} 2 \mathrm{X}_{2} / 3$ and $\mathrm{P} 2 \mathrm{X}_{3}$ receptors. In the presence of A-317491 both thermal hyperalgesia and mechanical allodynia were attenuated after chronic nerve constriction injury in which $\mathrm{P} 2 \mathrm{X}_{3}$ homomeric and $\mathrm{P} 2 \mathrm{X}_{2} / 3$ heteromeric receptor activities were involved. Although active in chronic pain models, A-317491 was ineffective in reducing nociception in animal 
models of acute postoperative pain and visceral pain indicating that $\mathrm{P} 2 \mathrm{X}_{3}$ and $\mathrm{P} 2 \mathrm{X}_{2} / 3$ receptor activation may not be a major mediator of acute postoperative or visceral pain [149]. MRS 2179 (2'-deoxy- $N^{6}$-methyladenosine $3^{\prime}, 5^{\prime}$ -bisphosphate) was discovered as a specific inhibitor of $\mathrm{P}_{2} \mathrm{Y}_{1}$ receptor activity [194]. This compound has an efficient antithrombotic action in which $\mathrm{P}_{2} \mathrm{Y}_{1}$ receptors are involved [195].

Based on structure design or combinatorial library approaches specific agonists or antagonists may be discovered for other purinergic receptor subtypes. For instance, the SELEX (systematic evolution of ligands by exponential enrichment) technique provides a particularly promising approach for the discovery of such compounds. This technique is based on the reiterative presentation of a partial random RNA or single-stranded DNA library to a protein preparation containing a particular purinergic receptor subtype. RNA or DNA molecules bound to a target site on the receptor are displaced from the receptor and eluted by addition of an excess concentration of an unspecific purinergic receptor antagonist and amplified by reverse transcription polymerase chain reaction (PCR) or PCR to restore the library used for the next in vitro selection cycle. Using this approach, it was possible to identify inhibitors specific for isoforms of a target protein [196]. Our group prepared membrane protein fractions of $1321 \mathrm{~N} 1$ cells stably transfected with rat $\mathrm{P} 2 \mathrm{X}_{2}$ receptors and coupled them onto an immobilized artificial membrane (IAM) as matrix for affinity chromatography. The equilibrium binding to the receptor and competition between ATP and the purinergic antagonists suramin and $2^{\prime} 3^{\prime}-O-(2,4,6-$ trinitrophenyl) adenosine $5^{\prime}$-triphosphate (TNP-ATP) were analyzed by a chromatographic assay using $\left[\alpha{ }^{32} \mathrm{P}\right]$-ATP as a radioligand. Our data indicate that suramin does not compete with ATP for the ligand binding site and TNP-ATP is a competitive antagonist, as already shown by Trujillo et al. [197]. Moreover, this chromatographic assay can be used in in vitro selection procedures for RNA aptamers binding to $\mathrm{P} 2 \mathrm{X}_{2}$ receptors from a combinatorial SELEX RNA library [198]. The development of a subtype-specific P2X receptor antagonist by using the SELEX technique or another combinatorial library-based approach shall serve as proof of principle and encourage further works to obtain such specific antagonists for all P2 receptor subtypes as tools for elucidating their biological functions and for possible therapeutic applications.

\section{Conclusion}

$\mathrm{P} 2$ receptor function is involved in most physiological processes and participates in neurotransmission in the CNS. Results obtained with mouse ES and P19 EC and neural progenitor cells suggest an important role of purinergic signaling in early embryogenesis, especially in cell proliferation, migration, and differentiation, with different subtypes of receptors participating in these processes. Our understanding of the biological functions of specific P2 receptor subtypes during CNS development and in the adult brain has increased due to the availability of knockout animals and specific inhibition of gene expression or activity of purinergic receptor subtypes. The importance of $\mathrm{P} 2$ receptor signaling in neuroprotection, neuroimmunity, and guiding neuronal differentiation, especially in glial and microglial cells, has been related to purinergic receptor expression. Most importantly, specific agonists and antagonists for individual P2 receptor subtypes are both needed for studying their involvement in biological processes. The discovery of such selective compounds will elucidate yet unknown biological functions of P2 receptor subtypes as well as open new avenues for therapeutic approaches to disease states in which purinergic receptor activity is involved.

Acknowledgments H.U. and L.R.G.B. are grateful for grant support from FAPESP (Fundação de Amparo à Pesquisa do Estado de São Paulo) and $\mathrm{CNPq}$ (Conselho Nacional de Desenvolvimento Científico e Tecnológico), Brazil. K.N.G.'s Ph.D. thesis is supported by fellowship from CAPES (Coordenação de Aperfeiçoamento de Pessoal de Nível Superior). C.L.G.'s undergraduate research, C.A. T.'s and K.K.Y.'s Ph.D. theses and R.R.R.'s postdoctoral research are supported by fellowships from FAPESP. P.M.'s Ph.D. thesis was supported by fellowship from FAPESP.

\section{References}

1. Evans RJ, Derkach V, Surprenant A (1992) ATP mediates fast synaptic transmission in mammalian neurons. Nature 357: 503-505

2. Silinsky EM, Gerzanich V, Vanner SM (1992) ATP mediates excitatory synaptic transmission in mammalian neurones. Br J Pharmacol 106:762-763

3. Burnstock G (1978) A basis for distinguishing two types of purinergic receptor. In: Straub RW, Bolis L (eds) Cell membrane receptors for drugs and hormones: a multidisciplinary approach. Raven, New York, pp 107-118

4. Burnstock G, Kennedy C (1985) Is there a basis for distinguishing two types of P2 purinoceptor? Gen Pharmacol 16:433-440

5. Brandle U, Zenner H-P, Ruppersberg JP (1999) Gene expression of $\mathrm{P} 2 \mathrm{X}$ receptors in the developing inner ear of the rat. Neurosci Lett 273:105-108

6. Adrian K, Bernhard MK, Breitinger H-G et al (2000) Expression of purinergic receptors (ionotropic $\mathrm{P} 2 \mathrm{X} 1-7$ and metabotrophic P2Y1-11) during myeloid differentiation of HL60 cells. Biochim Biophys Acta 1492:127-138

7. Orriss, IR, Knight GE, Ranasinghe S et al (2006) Osteoblast responses to nucleotides increase during differentiation. Bone 39:300-309

8. Berchtold S, Ogilvie ALL, Bogdan C et al (1999) Human monocyte derived dendritic cells express functional $\mathrm{P} 2 \mathrm{X}$ and $\mathrm{P} 2 \mathrm{Y}$ receptors as well as ecto-nucleotidases. FEBS Lett 458:424-428 
9. Ryten M, Dunn PM, Neary JT et al (2002) ATP regulates the differentiation of mammalian skeletal muscle by activation of a P2X5 receptor on satellite cells. J Cell Biol 158:345-355

10. Wang L, Jacobsen SE, Bengtsson A et al (2004) P2 receptor mRNA expression profiles in human lymphocytes, monocytes and CD34+ stem and progenitor cells. BMC Immunol 5:16

11. Huang N, Wang DJ, Heppel LA (1989) Extracellular ATP is a mitogen for 3T3, 3T6, and A431 cells and acts synergistically with other growth factors. Proc Natl Acad Sci U S A 86: 7904-7908

12. Neary JT, Whittemore SR, Zhu Q et al (1994). Synergistic activation of DNA synthesis in astrocytes by fibroblast growth factor and extracellular ATP. J Neurochem 63:490-494

13. Lemoli RM, Ferrari D, Fogli $M$ et al (2004) Extracellular nucleotides are potent stimulators of human hematopoietic stem cells in vitro and in vivo. Blood 104:1662-1670

14. Neary JT, Zhu Q (1994) Signaling by ATP receptors in astrocytes. Neuroreport 5:1617-1620

15. Lenz G, Gottfried C, Luo ZJ et al (2000) P2Y purinoceptor subtypes recruit different Mek activators in astrocytes. $\mathrm{Br} \mathrm{J}$ Pharmacol 129:927-936

16. Salter M, Hicks JL (1995) ATP causes release of intracellular $\mathrm{Ca} 2+$ via the phospholipase $\mathrm{C}$ beta/IP3 pathway in astrocytes from the dorsal spinal cord. J Neurosci 15:2961-2971

17. Miranov SL (1994) Metabotropic ATP receptor in hippocampal and thalamic neurones: pharmacology and modulation of $\mathrm{Ca} 2+$ mobilizing mechanisms. Neuropharmacology 33:1-13

18. Spitzer NC, Root CM, Borodinsky LN (2004) Orchestrating neuronal differentiation: patterns of $\mathrm{Ca} 2+$ spikes specify transmitter choice. Trends Neurosci 27:415-421

19. Gu X, Spitzer NC (1997) Breaking the code: regulation of neuronal differentiation by spontaneous calcium transients. Dev Neurosci 19:33-41

20. Zimmermann H (1996) Biochemistry, localization and functional roles of ecto-nucleotidases in the nervous system. Prog Neurobiol 49:589-618

21. Götz M, Huttner WB (2005) The cell biology of neurogenesis. Nat Rev Mol Cell Biol 6:777-788

22. Abbracchio MP, Burnstock G (1998) Purinergic signaling: pathophysiological roles. Jpn J Pharmacol 78:113-145

23. Laasberg $\mathrm{T}$ (1990) Ca2+-mobilizing receptors of gastrulating chick embryo. Comp Biochem Physiol C Pharmacol Toxicol Endocrinol 97:9-12

24. Katz LC, Shatz CJ (1996) Synaptic activity and the construction of cortical circuits. Science 274:1133-1138

25. Weissman TA, Riquelme PA, Ivic L et al (2004) Calcium waves propagate through radial glial cells and modulate proliferation in the developing neocortex. Neuron 43:647-661

26. Cicirata F, Meli C, Castorina C et al (1991) Neurotransmitter amino acid levels in rat thalamus and cerebral cortex after cerebellectomy. Int J Dev Neurosci 9:365-369

27. Miranda-Contreras L, Mendoza-Briceno RV, Palacios-Pru EL (1998) Levels of monoamine and amino acid neurotransmitters in the developing male mouse hypothalamus and in histotypic hypothalamic cultures. Int J Dev Neurosci 16:403-412

28. Miranda-Contreras L, Benitez-Diaz PR, Mendoza-Briceno RV et al (1999) Levels of amino acid neurotransmitters during mouse cerebellar neurogenesis and in histotypic cerebellar cultures. Dev Neurosci 21:147-158

29. Miranda-Contreras L, Ramirez-Martens LM, Benitez-Diaz PR et al (2000) Levels of amino acid neurotransmitters during mouse olfactory bulb neurogenesis and in histotypic olfactory bulb cultures. Int J Dev Neurosci 18:83-91

30. Flint AC, Liu X, Kriegstein AR (1998) Nonsynaptic glycine receptor activation during early neocortical development. Neuron 20:43-53
31. Haydar TF, Wang F, Schwartz ML et al (2000) Differential modulation of proliferation in the neocortical ventricular and subventricular zones. J Neurosci 20:5764-5774

32. Evans MJ, Kaufman M (1981) Establishment in culture of pluripotent cells from mouse embryos. Nature 292:154-156

33. McWhir J, Schnieke AE, Ansell R et al (1996) Selective ablation of differentiated cells permits isolation of embryonic stem cell lines from murine embryos with a non-permissive genetic background. Nat Genet 14:223-226

34. Heo SJ, Han HJ (2006) ATP stimulates mouse embryonic stem cell proliferation via protein kinase $\mathrm{C}$, phosphatidylinositol 3kinase/Akt, and mitogen-activated protein kinase signaling pathways. Stem Cells 24:2637-2648

35. Anneren C, Cowan CA, Melton DA (2004) The Src family of tyrosine kinases is important for embryonic stem cell selfrenewal. J Biol Chem 279:31590-31598

36. Martin GR (1981) Isolation of a pluripotent cell line from early mouse embryos cultured in medium conditioned by teratocarcinoma stem cells. Proc Natl Acad Sci U S A 78:7634-7638

37. Ulrich H, Majumder P (2006) Neurotransmitter receptor expression and activity during neuronal differentiation of embryonal carcinoma and stem cells: from basic research towards clinical applications. Cell Prolif 39:281-300

38. Resende RR, Majumder P, Gomes KN et al (2007) P19 embryonal carcinoma cells as in vitro model for studying purinergic receptor expression and modulation of N-methyl-daspartate-glutamate and acetylcholine receptors during neuronal differentiation. Neuroscience 146:1169-1181

39. da Silva RL, Resende RR, Ulrich H (2007) Alternative splicing of $\mathrm{P} 2 \mathrm{X} 6$ receptors in developing mouse brain and during in vitro neuronal differentiation. Exp Physiol 92:139-415

40. Gage FH, Coates PW, Palmer TD et al (1995) Survival and differentiation of adult neuronal progenitor cells transplanted to the adult brain. Proc Natl Acad Sci U S A 92:1187911883

41. Hogg RC, Chipperfield H, Whyte KA et al (2004) Functional maturation of isolated neural progenitor cells from the adult rat hippocampus. Eur J Neurosci 19:2410-2420

42. Pluchino S, Zanotti L, Deleidi M et al (2005) Neural stem cells and their use as therapeutic tool in neurological disorders. Brain Res Rev 48:211-219

43. Cameron HA, Tanapat P, Gould E (1998) Adrenal steroids and $\mathrm{N}$-methyl-D-aspartate receptor activation regulate neurogenesis in the dentate gyrus of adult rats through a common pathway. Neuroscience 82:349-354

44. Svendsen CN, ter Borg MG, Armstrong RJ et al (1998) A new method for the rapid and long term growth of human neural precursor cells. J Neurosci Methods 85:141-152

45. Shukla V, Zimmermann H, Wang L et al (2005) Functional expression of the ecto-ATPase NTPDase 2 and of nucleotide receptors by neuronal progenitor cells in the adult murine hippocampus. J Neurosci Res 80:600-610

46. Braun N, Sevigny J, Mishra SK et al (2003) Expression of the ecto-ATPase NTPDase2 in the germinal zones of the developing and adult rat brain. Eur J Neurosci 17:1355-1364

47. Mishra SK, Braun N, Shukla V et al (2006) Extracellular nucleotide signaling in adult neural stem cells: synergism with growth factor-mediated cellular proliferation. Development 133:675-684

48. Leon C, Hechler B, Freund M et al (1999) Defective platelet aggregation and increased resistance to thrombosis in purinergic P2Y(1) receptor-null mice. J Clin Invest 104:1731-1737

49. Lin JH, Takano T, Arcuino G et al (2007) Purinergic signaling regulates neural progenitor cell expansion and neurogenesis. Dev Biol 302:356-366 
50. Ryu JK, Choi HB, Hatori K et al (2003) Adenosine triphosphate induces proliferation of human neural stem cells: role of calcium and p70 ribosomal protein S6 kinase. J Neurosci Res 72: 352-362

51. Tran PB, Ren D, Veldhouse TJ et al (2004) Chemokine receptors are expressed widely by embryonic and adult neural progenitor cells. J Neurosci Res 76:20-34

52. Safiulina VF, Kasyanov AM, Sokolova E et al (2005) ATP contributes to the generation of network-driven giant depolarizing potentials in the neonatal rat hippocampus. J Physiol 565:981-992

53. Heine C, Heimrich B, Vogt J et al (2006) P2 receptor-stimulation influences axonal outgrowth in the developing hippocampus in vitro. Neuroscience 138:303-311

54. Burnstock G (1996) Development and perspectives of the purinoceptor concept. J Auton Pharmacol 16:295-302

55. Torres IL, Battastini AM, Buffon A et al (2003) Ectonucleotidase activities in spinal cord of rats changes as function of age. Int J Dev Neurosci 21:425-429

56. Cheung KK, Burnstock $\mathrm{G}$ (2002) Localization of $\mathrm{P} 2 \mathrm{X}_{3}$ receptors and coexpression with $\mathrm{P} 2 \mathrm{X}_{2}$ receptors during rat embryonic neurogenesis. J Comp Neurol 443:368-382

57. Cheung KK, Ryten M, Burnstock G (2003) Abundant and dynamic expression of $\mathrm{G}$ protein-coupled $\mathrm{P} 2 \mathrm{Y}$ receptors in mammalian development. Dev Dyn 228:254-266

58. Cheung KK, Chan WY, Burnstock G (2005) Expression of P2X purinoceptors during rat brain development and their inhibitory role on motor axon outgrowth in neural tube explant cultures. Neuroscience 133:937-945

59. Xiang Z, Burnstock G (2005) Expression of P2X receptors on rat microglial cells during early development. Glia 52:119-126

60. Kidd EJ, Miller KJ, Sansum AJ et al (1998) Evidence for P2X3 receptors in the developing rat brain. Neuroscience 87:533-539

61. Brosenitsch TA, Adachi T, Lipski J et al (2005) Developmental downregulation of $\mathrm{P} 2 \mathrm{X} 3$ receptors in motoneurons of the compact formation of the nucleus ambiguous. Eur $\mathrm{J}$ Neurosci 22:809-824

62. Narcisse L, Scemes E, Zhao Y et al (2005) The cytokine IL-1beta transiently enhances $\mathrm{P} 2 \mathrm{X} 7$ receptor expression and function in human astrocytes. Glia 49:245-258

63. Sperlágh B, Köfalvi A, Deuchars D et al (2002) Involvement of $\mathrm{P} 2 \mathrm{X}_{7}$ receptors in the regulation of neurotransmitter release in the rat hippocampus. J Neurochem 81:1196-1211

64. Feuvre RL, Brough D, Rothwell N (2002) Extracellular ATP and $\mathrm{P}_{2} \mathrm{X}_{7}$ receptors in neurodegeneration. Eur $\mathrm{J}$ Pharmacol 447: 261-269

65. Xiang Z, Burnstock G (2005) Changes in expression of P2X purinoreceptor in rat cerebellum during postnatal development. Dev Brain Res 156:147-157

66. Lalo U, Voitenko N, Kostyuk P (1998) Iono- and metabotropically induced purinergic calcium signalling in rat neocortical neurons. Brain Res 799:285-291

67. Ciccolini F, Collins TJ, Sudhoelter J et al (2003) Local and global spontaneous calcium events regulate neurite outgrowth and onset of GABAergic phenotype during neural precursor differentiation. J Neurosci 23:103-111

68. Maric D, Maric I, Chang YH et al (2003) Prospective cell sorting of embryonic rat neural stem cells and neuronal and glial progenitors reveals selective effects of basic fibroblast growth factor and epidermal growth factor on self-renewal and differentiation. J Neurosci 23:240-251

69. Scemes E, Duval N, Meda P (2003) Reduced expression of P2Y1 receptors in connexin43-null mice alters calcium signaling and migration of neural progenitor cells. J Neurosci 23:11444-11452

70. Hyden H (1961) Satellite cells in the nervous system. Sci Am 205:62-70
71. Vernadakis A (1996) Glia-neuron intercommunications and synaptic plasticity. Prog Neurobiol 49:185-214

72. Imura T, Kornblum HI, Sofroniew MV (2003) The predominant neural stem cell isolated from postnatal and adult forebrain but not early embryonic forebrain expresses GFAP. J Neurosci 23:2824-2832

73. Garcia AD, Doan NB, Imura T et al (2004) GFAP-expressing progenitors are the principal source of constitutive neurogenesis in adult mouse forebrain. Nat Neurosci 7:1233-1241

74. Powell EM, Geller HM (1999) Dissection of astrocyte-mediated cues in neuronal guidance and process extension. Glia 26:73-83

75. Merkle FT, Alvarez-Buylla A (2006) Neural stem cells in mammalian development. Curr Opin Cell Biol 18:704-709

76. Song H, Stevens CF, Gage FH (2002) Astroglia induce neurogenesis from adult neural stem cells. Nature 417:39-44

77. Svendsen CN (2002) The amazing astrocyte. Nature 417:29-32

78. Montgomery DL (1994) Astrocytes: form, functions, and roles in disease. Vet Pathol 31:145-167

79. Rose CR, Ransom BR (1997) Gap junctions equalize intracellular $\mathrm{Na}+$ concentration in astrocytes. Glia 20:299-307

80. Cotrina ML, Lin JH, Alves-Rodrigues A et al (1998) Connexins regulate calcium signaling by controlling ATP release. Proc Natl Acad Sci U S A 95:15735-15740

81. Cotrina ML, Lin JH, Nedergaard M (1998) Cytoskeletal assembly and ATP release regulate astrocytic calcium signaling. J Neurosci 18:8794-8804

82. Ciccarelli R, Ballerini P, Sabatino G et al (2001) Involvement of astrocytes in purine-mediated reparative processes in the brain. Int J Dev Neurosci 19:395-414

83. Fields RD, Stevens-Graham B (2002) New insights into neuronglia communication. Science 298:556-562

84. Hansson E, Ronnback L (2003) Glial neuronal signaling in the central nervous system. FASEB J 17:341-348

85. Hagg T (2005) Molecular regulation of adult CNS neurogenesis: an integrated view. Trends Neurosci 28:589-595

86. Araque A, Perea G (2004) Glial modulation of synaptic transmission in culture. Glia 47:241-248

87. Lin SC, Bergles DE (2004) Synaptic signaling between neurons and glia. Glia 47:290-298

88. Araque A, Carmignoto G, Haydon PG (2001) Dynamic signaling between astrocytes and neurons. Annu Rev Physiol 63:795-813

89. Hertz L, Zielke HR (2004) Astrocytic control of glutamatergic activity: astrocytes as stars of the show. Trends Neurosci 27:735743

90. Cotrina ML, Lin JH, Lopez-Garcia JC et al (2000) ATP-mediated glia signaling. J Neurosci 20:2835-2844

91. Fields RD, Burnstock G (2006) Purinergic signalling in neuronglia interactions. Nat Rev Neurosci 7:423-436

92. Chaudry IH (1982) Does ATP cross the cell plasma membrane. Yale J Biol Med 55:1-10

93. Fields RD, Stevens B (2000) ATP: an extracellular signaling molecule between neurons and glia. Trends Neurosci 23:625-633

94. Vizi ES, Burnstock G (1988) Origin of ATP release in the rat vas deferens: concomitant measurement of $[3 \mathrm{H}]$ noradrenaline and [14C]ATP. Eur J Pharmacol 158:69-77

95. Bodin P, Burnstock G (2001) Purinergic signalling: ATP release. Neurochem Res 26:959-969

96. Edwards FA, Gibb AJ, Colquhoun D (1992) ATP receptor mediated synaptic currents in the central nervous system. Nature 359:144-146

97. Mori M, Heuss C, Gahwiler BH et al (2001) Fast synaptic transmission mediated by $\mathrm{P} 2 \mathrm{X}$ receptors in $\mathrm{CA} 3$ pyramidal cells of rat hippocampal slice cultures. J Physiol 535:115-123

98. Reisin IL, Prat AG, Abraham EH et al (1994) The cystic fibrosis transmembrane conductance regulator is a dual ATP and chloride channel. J Biol Chem 269:20584-20591 
99. Schwiebert EM (1999) ABC transporter-facilitated ATP conductive transport. Am J Physiol 276:C1-C8

100. Stout CE, Costantin JL, Naus CC et al (2002) Intercellular calcium signaling in astrocytes via ATP release through connexin hemichannels. J Biol Chem 277:10482-10488

101. Suadicani SO, Brosnan CF, Scemes E (2006) P2X7 receptors mediate ATP release and amplification of astrocytic intercellular $\mathrm{Ca}^{2+}$ signaling. J Neurosci 26:1378-1385

102. Franke H, Krugel U, Illes P (2006) P2 receptors and neuronal injury. Pflugers Arch 452:622-644

103. Zimmermann H (2000) Extracellular metabolism of ATP and other nucleotides. Naunyn Schmiedebergs Arch Pharmacol 362:299-309

104. Ralevic V, Burnstock G (1998) Receptors for purines and pyrimidines. Pharmacol Rev 50:413-492

105. Ribeiro JA, Sebastiao AM, de Mendonca A (2003) Participation of adenosine receptors in neuroprotection. Drug News Perspect 16:80-86

106. Bennett MR, Buljan V, Farnell L et al (2006) Purinergic junctional transmission and propagation of calcium waves in spinal cord astrocyte networks. Biophys J 91:3560-3571

107. Butt AM (2006) Neurotransmitter-mediated calcium signalling in oligodendrocyte physiology and pathology. Glia 54:666-675

108. Walz W, Gimpl G, Ohlemeyer C et al (1994) Extracellular ATPinduced currents in astrocytes: involvement of a cation channel. J Neurosci Res 38:12-18

109. Franke H, Illes $P$ (2006) Involvement of P2 receptors in the growth and survival of neurons in the CNS. Pharmacol Ther 109:297-324

110. Deitmer JW, Verkhratsky AJ, Lohr C (1998) Calcium signalling in glial cells. Cell Calcium 24:405-416

111. Vesce S, Bezzi P, Volterra A (1999) The active role of astrocytes in synaptic transmission. Cell Mol Life Sci 56:991-1000

112. Dani JW, Chernjavsky A, Smith SJ (1992) Neuronal activity triggers calcium waves in hippocampal astrocyte networks. Neuron 8:429-440

113. Guthrie PB, Knappenberger J, Segal M et al (1999) ATP released from astrocytes mediates glial calcium waves. J Neurosci 19:520-528

114. Zhang JM, Wang HK, Ye CQ et al (2003) ATP released by astrocytes mediates glutamatergic activity-dependent heterosynaptic suppression. Neuron 40:971-982

115. Innocenti B, Parpura V, Haydon PG (2000) Imaging extracellular waves of glutamate during calcium signaling in cultured astrocytes. J Neurosci 20:1800-1808

116. Fam SR, Gallagher CJ, Salter MW (2000) P2Y(1) purinoceptormediated $\mathrm{Ca}(2+)$ signaling and $\mathrm{Ca}(2+)$ wave propagation in dorsal spinal cord astrocytes. J Neurosci 20:2800-2808

117. Domercq M, Brambilla L, Pilati E et al (2006) P2Y1 receptorevoked glutamate exocytosis from astrocytes: control by tumor necrosis factor-alpha and prostaglandins. J Biol Chem 281:30684-30696

118. Agrestia C, Meomartinib ME, Amadiob S et al (2005) ATP regulates oligodendrocyte progenitor migration, proliferation, and differentiation: involvement of metabotropic P2 receptors. Brain Res Rev 48:157-165

119. Burnstock G (2006) Pathophysiology and therapeutic potential of purinergic signaling. Pharmacol Rev 58:58-86

120. Gysbers JW, Rathbone MP (1992) Guanosine enhances NGFstimulated neurite outgrowth in PC12 cells. Neuroreport 3 (11):997-1000

121. D'Ambrosi N, Cavaliere F, Merlo D et al (2000) Antagonists of P2 receptor prevent NGF-dependent neuritogenesis in PC12 cells. Neuropharmacology 39:1083-1094

122. D'Ambrosi N, Murra B, Cavaliere F et al (2001) Interaction between ATP and nerve growth factor signalling in the survival and neuritic outgrowth from PC12 cells. Neuroscience 108:527534

123. Sanches G, de Alencar LS, Ventura AL (2002) ATP induces proliferation of retinal cells in culture via activation of $\mathrm{PKC}$ and extracellular signal-regulated kinase cascade. Int J Dev Neurosci 20:21-27

124. Braumann T, Jastorff B, Richter-Landsberg C (1986) Fate of cyclic nucleotides in PC12 cell cultures: uptake, metabolism, and effects of metabolites on nerve growth factor-induced neurite outgrowth. J Neurochem 47:912-919

125. Wang CM, Chang YY, Kuo JS et al (2002) Activation of P2X(7) receptors induced $[(3) \mathrm{H}] \mathrm{GABA}$ release from the RBA-2 type-2 astrocyte cell line through a $\mathrm{Cl}(-) / \mathrm{HCO}(3)(-))$-dependent mechanism. Glia 37:8-18

126. Kucher BM, Neary JT et al (2005) Bi-functional effects of ATP/ $\mathrm{P} 2$ receptor activation on tumor necrosis factor- $\alpha$ release in lipopolysaccharide-stimulated astrocytes. J Neurochem 92: 525-535

127. Krügel U, Kittner H, Franke $H$ et al (2001) Accelerated functional recovery after neuronal injury by $\mathrm{P} 2$ receptor blockade. Eur J Pharmacol 420:R3-R4

128. Sebastião AM, de Mendonça A, Ribeiro JA et al (2001) Neuroprotection during hypoxic insults: role of adenosine. Drug Dev Res 52:291-295

129. Kaya N, Tanaka S, Koike T et al (2002) ATP selectively suppresses the synthesis of the inflammatory protein microglial response factor (MRF)-1 through $\mathrm{Ca} 2+$ influx via $\mathrm{P} 2 \mathrm{X} 7$ receptors in cultured microglia. Brain Res 952:86-97

130. Gendron FP, Chalimoniuk M, Strosznajder J et al (2003) P2X7 nucleotide receptor activation enhances IFN gamma-induced type II nitric oxide synthase activity in BV-2 microglial cells. J Neurochem 87:344-352

131. Ohtani Y, Minami M, Satoh M et al (2000) Expression of inducible nitric oxide synthase mRNA and production of nitric oxide are induced by adenosine triphosphate in cultured rat microglia. Neurosci Lett 293:72-74

132. Ferrari D, Chiozzi P, Falzoni S et al (1997) Purinergic modulation of interleukin- $1 \beta$ release from microglial cells stimulated with bacterial endotoxin. J Exp Med 185:579582

133. Hide I, Tanaka M, Inoue A et al (2000) Extracellular ATP triggers tumor necrosis factor alpha release from rat microglia. $\mathrm{J}$ Neurochem 75:965-972

134. Humphreys BD, Rice J, Kertesy SB et al (2000) Stress-activated protein kinase/JNK activation and apoptotic induction by the macrophage P2X7 nucleotide receptor. J Biol Chem 275:2679226798

135. Shigemoto-Mogami Y, Koizumi S, Tsuda M et al (2001) Mechanisms underlying extracellular ATP-evoked interleukin-6 release in mouse microglial cell line, MG-5. J Neurochem 78:1339-1349

136. Inoue K, Nakajima K, Morimoto T et al (1998) ATP stimulation of $\mathrm{Ca} 2+$-dependent plasminogen release from cultured microglia. Br J Pharmacol 123:1304-1310

137. Khakh BS (2001) Molecular physiology of P2X receptors and ATP signalling at synapses. Nat Rev Neurosci 2:165-174

138. Knutsen LJ, Murray TF et al (1997) Adenosine and ATP in epilepsy. In: Jacobson KA, Jarvis (eds) Purinergic approaches in experimental therapeutics. Wiley-Liss, Danvers, MA

139. Kang TC, An SJ, Park SK et al (2003) P2X2 and P2X4 receptor expression is regulated by a GABA(A) receptor-mediated mechanism in the gerbil hippocampus. Mol Brain Res 116:168-175

140. Kang TC, Park SK, Hwang IK et al (2004) GABA(B) receptormediated regulation of $\mathrm{P} 2 \mathrm{X} 7$ receptor expression in the gerbil hippocampus. Mol Brain Res 121:12-18 
141. Stoeckel ME, Uhl-Bronner S, Hugel S et al (2003) Cerebrospinal fluid-contacting neurons in the rat spinal cord, a gammaaminobutyric acidergic system expressing the P2X2 subunit of purinergic receptors, PSA-NCAM, and GAP-43 immunoreactivities: light and electron microscopic study. J Comp Neurol 457:159-174

142. Labrakakis C, Tong CK, Weissman T et al (2003) Localization and function of ATP and GABAA receptors expressed by nociceptors and other postnatal sensory neurons in rat. J Physiol 549:131-142

143. Chen CC, Akopian AN, Sivilotti L et al (1995) A P2X purinoceptor expressed by a subset of sensory neurons. Nature 377:428-431

144. Lewis CJ, Neidhart S, Holy C et al (1995) Coexpression of P2X2 and $\mathrm{P} 2 \mathrm{X} 3$ receptor subunits can account for ATP-gated currents in sensory neurones. Nature 377:432-434

145. Khakh BS, Humphrey PP, Surprenant A (1995) Electrophysiological properties of P2X-purinoceptors in rat superior cervical, nodose and guinea-pig coeliac neurones. J Physiol 484:385-395

146. Cockayne DA, Hamilton SG, Zhu QM et al (2000) Urinary bladder hyporeflexia and reduced pain-related behaviour in P2X3-deficient mice. Nature 407:1011-1015

147. Souslova V, Cesare P, Ding Y et al (2000) Warm-coding deficits and aberrant inflammatory pain in mice lacking $\mathrm{P} 2 \mathrm{X} 3$ receptors. Nature 407:1015-1017

148. North RA (2003) The P2X3 subunit: a molecular target in pain therapeutics. Curr Opin Investig Drugs 4:833-840

149. Jarvis MF, Burgard EC, McGaraughty S et al (2002) A-317491, a novel potent and selective non-nucleotide antagonist of P2X3 and $\mathrm{P} 2 \mathrm{X} 2 / 3$ receptors, reduces chronic inflammatory and neuropathic pain in the rat. Proc Natl Acad Sci U S A 99:17179-17184

150. Tsuda M, Shigemoto-Mogami Y, Koizumi S et al (2003) P2X4 receptors induced in spinal microglia gate tactile allodynia after nerve injury. Nature 424:778-783

151. Haughey NJ, Mattson MP (2003) Alzheimer's amyloid betapeptide enhances ATP/gap junction-mediated calcium-wave propagation in astrocytes. Neuromol Med 3:173-180

152. Exley C, Korchazhkina OV (2001) Promotion of formation of amyloid fibrils by aluminium adenosine triphosphate (AlATP). J Inorg Biochem 84:215-224

153. Rampe D, Wang L, Ringheim GE et al (2004) P2X7 receptor modulation of beta-amyloid- and LPS-induced cytokine secretion from human macrophages and microglia. J Neuroimmunol 147:56-61

154. Parvathenani LK, Tertyshnikova S, Greco CR et al (2003) P2X7 mediates superoxide production in primary microglia and is upregulated in a transgenic mouse model of Alzheimer's disease. $\mathrm{J}$ Biol Chem 278:13309-13317

155. Moore D, Chambers J, Waldvogel H et al (2000) Regional and cellular distribution of the $\mathrm{P} 2 \mathrm{Y} 1$ purinergic receptor in the human brain: striking neuronal localisation. J Comp Neurol 421:374-384

156. Moore D, Iritani S, Chambers J et al (2000) Immunohistochemical localization of the $\mathrm{P} 2 \mathrm{Y} 1$ purinergic receptor in Alzheimer's disease. Neuroreport 11:3799-3803

157. Braun N, Zhu Y, Krieglstein J et al (1998) Upregulation of the enzyme chain hydrolyzing extracellular ATP after transient forebrain ischemia in the rat. J Neurosci 18:4891-4900

158. Melani A, Turchi D, Vannucchi MG et al (2005) ATP extracellular concentrations are increased in the rat striatum during in vivo ischemia. Neurochem Int 47:442-448

159. Phillis JW, O'Regan MH, Perkins LM et al (1993) Adenosine 5'triphosphate release from the normoxic and hypoxic in vivo rat cerebral cortex. Neurosci Lett 151:94-96
160. Juranyi Z, Sperlagh B, Vizi ES et al (1999) Involvement of P2 purinoceptors and the nitric oxide pathway in $[3 \mathrm{H}]$ purine outflow evoked by short-term hypoxia and hypoglycemia in rat hippocampal slices. Brain Res 823:183-190

161. Cavaliere F, Florenzano F, Amadio S et al (2003) Up-regulation of $\mathrm{P} 2 \mathrm{X} 2, \mathrm{P} 2 \mathrm{X} 4$ receptor and ischemic cell death: prevention by P2 antagonists. Neuroscience 120:85-98

162. Cavaliere F, Amadio S, Sancesario G et al (2004) Synaptic P2X7 and oxygen/glucose deprivation in organotypic hippocampal cultures. J Cereb Blood Flow Metab 24:392-398

163. Franke H, Günther A, Grosche J et al (2004) $2 X 7$ receptor expression after ischemia in the cerebral cortex of rats. $\mathrm{J}$ Neuropathol Exp Neurol 63:686-699

164. Kim M, Jiang LH, Wilson HL et al (2001) Proteomic and functional evidence for a $\mathrm{P} 2 \mathrm{X} 7$ receptor signaling complex. EMBO J 2:6347-6358

165. Moran-Jimenez MJ, Matute C et al (2000) Immunohistochemical localization of the $\mathrm{P} 2 \mathrm{Y} 1$ purinergic receptor in neurons and glial cells of the central nervous system. Mol Brain Res 78:50-58

166. Viscomi MT, Florenzano F, Conversi D et al (2004) Axotomy dependent purinergic and nitrergic co-expression. Neuroscience 123:393-404

167. Tsuzuki K, Kondo E, Fukuoka T et al (2001) Differential regulation of $\mathrm{P} 2 \mathrm{X} 3 \mathrm{mRNA}$ expression by peripheral nerve injury in intact and injured neurons in the rat sensory ganglia. Pain 91:351-360

168. Wang X, Arcuino G, Takano T et al (2004) P2X7 receptor inhibition improves recovery after spinal cord injury. Nat Med 10:821-827

169. Florenzano F, Viscomi MT, Cavaliere F et al (2002) Cerebellar lesion up-regulates $\mathrm{P} 2 \mathrm{X} 1$ and $\mathrm{P} 2 \mathrm{X} 2$ purinergic receptors in precerebellar nuclei. Neuroscience 115:425-434

170. Viscomi MT, Florenzano F, Amadio S (2005) Partial resistance of ataxin-2-containing olivary and pontine neurons to axotomyinduced degeneration. Brain Res Bull 66:212-221

171. Arthur DB, Akassoglou K, Insel PA et al (2005) P2Y2 receptor activates nerve growth factor/TrkA signaling to enhance neuronal differentiation. Proc Natl Acad Sci U S A 102:19138-19143

172. Peković S, Filipovic R, Subasic S et al (2005) Downregulation of glial scarring after brain injury: the effect of purine nucleoside analogue ribavirin. Ann N Y Acad Sci 1048:296-310

173. Pines A, Bivi N, Vascotto C et al (2006) Nucleotide receptors stimulation by extracellular ATP controls Hsp90 expression through APE1/Ref-1 in thyroid cancer cells: a novel tumorigenic pathway. J Cell Physiol 209:44-55

174. Gerasimovskaya EV, Ahmad S, White CW et al (2002) Extracellular ATP is an autocrine/paracrine regulator of hypoxia-induced adventitial fibroblast growth. Signaling through extracellular signal-regulated kinase-1/2 and the Egr- 1 transcription factor. J Biol Chem 277:44638-44650

175. Murray AW (2004) Recycling the cell cycle: cyclins revisited. Cell 116:221-234

176. Morgan DA, Class R, Soslau G et al (1997) Cytokine-mediated erythroid maturation in megakaryoblastic human cell line HU-3. Exp Hematol 25:1378-1385

177. Sherr CJ, Roberts JM (2004) Living with or without cyclins and cyclin-dependent kinases. Genes Dev 18:2699-2711

178. Neary JT, Kang Y, Willoughby KA et al (2003) Activation of extracellular signal-regulated kinase by stretch-induced injury in astrocytes involves extracellular ATP and P2 purinergic receptors. J Neurosci 23:2348-2356

179. Budagian V, Bulanova E, Brovko L et al (2003) Signaling through $\mathrm{P} 2 \mathrm{X} 7$ receptor in human T cells involves p561ck, MAP kinases, and transcription factors AP-1 and NF-kappa B. J Biol Chem 278:1549-1560 
180. Ahmed-Choudhury J, Russell CL, Randhawa S et al (2003) Differential induction of nuclear factor-kappaB and activator protein-1 activity after CD40 ligation is associated with primary human hepatocyte apoptosis or intrahepatic endothelial cell proliferation. Mol Biol Cell 14:1334-1345

181. Krejci P, Bryja V, Pachernik J et al (2004) FGF2 inhibits proliferation and alters the cartilage-like phenotype of RCS cells. Exp Cell Res 297:152-164

182. Ahamed S, Foster JS, Bukovsky A et al (2001) Signal transduction through the Ras/Erk pathway is essential for the mycoestrogen zearalenone-induced cell-cycle progression in MCF-7 cells. Mol Carcinog 30:88-98

183. Cordova-Alarcon E, Centeno F, Reyes-Esparza J et al (2005) Effects of HRAS oncogene on cell cycle progression in a cervical cancer-derived cell line. Arch Med Res 36:311-316

184. Hideshima T, Nakamura N, Chauhan D et al (2001) Biologic sequelae of interleukin-6 induced PI3-K/Akt signaling in multiple myeloma. Oncogene 20:5991-6000

185. Glauser DA, Schlegel W (2007) Sequential actions of ERK1/2 on the AP-1 transcription factor allow temporal integration of metabolic signals in pancreatic (beta) cells. FASEB J (in press)

186. Chu TS, Wu MS, Wu KD et al (2007) Endothelin-1 activates MAPKs and modulates cell cycle proteins in OKP cells. J Formos Med Assoc 106:273-280

187. Migliaccio A, Castoria G, Di Domenico M et al (2002) Sex steroid hormones act as growth factors. J Steroid Biochem Mol Biol 83:31-35

188. Lents NH, Keenan SM, Bellone C et al (2002) Stimulation of the Raf/MEK/ERK cascade is necessary and sufficient for activation and Thr-160 phosphorylation of a nuclear-targeted CDK2. J Biol Chem 277:47469-47475

189. Reshetnikova G, Barkan R, Popov B et al (2000) Disruption of the actin cytoskeleton leads to inhibition of mitogen-induced cyclin $\mathrm{E}$ expression, Cdk2 phosphorylation, and nuclear accumulation of the retinoblastoma protein-related p107 protein. Exp Cell Res 259:35-53

190. Bhatt KV, Spofford LS, Aram G et al (2005) Adhesion control of cyclin D1 and p27Kip1 levels is deregulated in melanoma cells through BRAF-MEK-ERK signaling. Oncogene 24:3459-3471

191. Lefevre G, Calipel A, Mouriaux F et al (2003) Opposite longterm regulation of $\mathrm{c}-\mathrm{Myc}$ and $\mathrm{p} 27 \mathrm{Kip} 1$ through overactivation of Raf-1 and the MEK/ERK module in proliferating human choroidal melanoma cells. Oncogene 22:8813-8822

192. Delmas C, Manenti S, Boudjelal A et al (2001) The p42/p44 mitogen-activated protein kinase activation triggers $\mathrm{p} 27 \mathrm{Kip} 1$ degradation independently of CDK2/cyclin E in NIH 3 T3 cells. J Biol Chem 276:34958-34965

193. Zhang W, Lee JC, Kumar S et al (1999) ERK pathway mediates the activation of Cdk2 in IGF-1-induced proliferation of human osteosarcoma MG-63 cells. J Bone Miner Res 14:528-535

194. Boyer JL, Mohanram A, Camaioni E et al (1998) Competitive and selective antagonism of P2Y1 receptors by N6-methyl 2'-deoxyadenosine 3',5'-bisphosphate. Br J Pharmacol 124:1-3

195. Baurand A, Gachet C (2003) The P2Y(1) receptor as a target for new antithrombotic drugs: a review of the P2Y(1) antagonist MRS-2179. Cardiovasc Drug Rev 21:67-76

196. Ulrich H, Trujillo CA, Nery AA et al (2006) DNA and RNA aptamers: from tools for basic research towards therapeutic applications. Comb Chem High Throughput Screen 9:619-632

197. Trujillo CA, Nery AA, Martins AH et al (2006) Inhibition mechanism of the recombinant rat $\mathrm{P} 2 \mathrm{X}(2)$ receptor in glial cells by suramin and TNP-ATP. Biochemistry 45:224-233

198. Trujillo CA, Majumder P, Gonzalez FA et al (2007) Immobilized $\mathrm{P} 2 \mathrm{X}(2)$ purinergic receptor stationary phase for chromatographic determination of pharmacological properties and drug screening. J Pharm Biomed Anal 44:701-710 